\title{
SOME ASPECTS OF THE DEVELOPMENT OF THE MUSLIM UMMAH IN KARACHAY-CHERKESSIA IN 2011-2020
}

\author{
(C) Natalya V. Kratova
}

\author{
Karachay-Cherkess Institute of Humanitarian Research under the Government \\ of the KCR, \\ Cherkessk, Karachay-Cherkess Republic, Russian Federation \\ nvkratova@mail.ru
}

Some directions of the development of the Muslim ummah of Karachay-Cherkessia in the second decade of the $21^{\text {st }}$ century after the Report-and-election Congress of Muslims of Karachay-Cherkessia and Stavropol are shown. An overview of the state of affairs in the Spiritual Administration of KarachayCherkessia and Stavropol Territory at the end of the 2000s is given. Along with the obvious achievements that allowed the muftiate to take a worthy place in the social structure of the republic, by this time a serious set of contradictions had accumulated, requiring a reform of the muftiate's management system. First of all, the task was to make up for the human losses: prominent spiritual leaders who had great authority in the local ummah and were killed in several years. In addition, it was necessary to involve representatives of young educated clergy in the work of the muftiate. An important task was to prevent a split in spiritual unity in the conditions of the exit from the Muftiate of the Stavropol Ummah, which formed its own muftiate. The system of administration created after the Report-and-Election Congress of Muslims of Karachay-Cherkessia and Stavropol Territory is also examined in detail. The criterion of its effectiveness was the work on countering the ideology of extremism and terrorism. The presence of educated clergy in the system of governance by the muftiat made it possible to adequately resist the agitation of adherents of organizations banned in Russia and prevent the formation of an aura of "champions of truth" and "defenders of justice" among members of extremist cells. The negative side of the created scheme of governance of the muftiate was stagnation: for ten years, the governing bodies were practically not updated. An attempt to create a personal site ended in failure. During the same period, illegal armed formations of supporters of religious extremist ideology continued to appear in the republic, the elimination of which required significant efforts of law enforcement agencies.

Key words: Islam, Spiritual Directorate of Muslims of Karachay-Cherkessia and Stavropol Territory, Spiritual Directorate of Muslims of the Karachay-Cherkess Republic, Karachay-Cherkess Republic, countering terrorism.

\section{[Н.В. Кратова Некоторые аспекты развития мусульманской уммы Карачаево-Черкесии в 2011- 2020 гr.]}

Показаны некоторые направления развития мусульманской уммы Карачаево-Черкесии во втором десятилетии XXI века после проведения Восьмого отчетно-выборного съезда мусульман Карачаево-Черкесии и Ставрополья. Дается обзор положения дел в Духовном управлении КарачаевоЧеркесии и Ставрополье в конце нулевых. Наряду с очевидными достижениями, позволившими муфтияту занять достойное место в социальной структуре республики, к этому времени накопился серьезный комплекс противоречий, требующих проведения реформы системы управления муфтиятом. Прежде всего, стояла задача восполнить человеческие потери - за несколько лет были убиты видные духовные лидеры, пользовавшиеся большим авторитетом в местной умме. Кроме того, необходимо было привлечь к работе в муфтияте представителей молодого образованного духовенства. Важной задачей было не допустить раскола духовного единства в условиях выхода из состава муфтията ставропольской уммы, образовавшей собственный муфтият. Также подробно рассматривается система администрирования, созданная после Восьмого отчетно-выборного съезда мусульман Карачаево-Черкесии и Ставрополья. Критерием ее эффективности стала работа по противодействию идеологии экстремизма и терроризма. Наличие в системе уравления муфтиятом образованного духовенства позволило достойно противостоять агитации приверженцев запрещенных на территории России организаций и не допустить формирования у членов экстремистских ячеек ореола «поборников и правды» и «защитников справедливости». Негативной стороной созданной схемы управления муфтиятом стала некоторая стагнация: за десять лет органы управления практически не обновлялись. Неудачей завершилась попытка создания собственного сайта. В этот же период в республике 
продолжали появляться незаконные вооруженные формирования сторонников религиозной экстремистской идеологии, ликвидация которых требовала значительных усилий правоохранительных органов.

Ключевые слова: ислам, Духовное управление мусульман Карачаево-Черкесии и Ставрополья, Духовное управление мусульман Карачаево-Черкесской Республики, Карачаево-Черкесская республика, противодействие терроризму.

Natalya V. Kratova - Ph.D. in History, Associate Professor, Karachay-Cherkess Institute of Humanitarian Research under the Government of the KCR, Cherkessk, Karachay-Cherkess Republic, Russian Federation.

Кратова Наталья Васильевна - кандидат исторических наук, доцент, Карачаево-Черкесский институт гуманитарных исследований при Правительстве КЧР, г. Черкесск, Карачаево-Черкесская республика, Российская Федерация.

The second decade of the twentieth century was a time of serious changes in the life of the Spiritual Directorate of Muslims of the Karachay-Cherkess Republic. (later KCR) By this time, the Muftiate was a fully formed organization with a well-established internal management system, established relations with Federal and regional authorities, and strong ties with the Muslim communities of the North and South Caucasus.

According to the 2010 census, there were 311,983 ethnic Muslims living in the Republic, which accounted for $65.28 \%$ of the total population of the republic. The muftiat consisted of 130 Muslim communities, of which 111 Muslim religious organizations were registered in Russian Ministry of Justice's Office for the KCR. There were 117 mosques. Since 1993, the Karachay-Cherkess Islamic Institute named after Imam Abu Hanif has been operating in the republic, which was the main base for the training and retraining of Muslim clergy personnel. In addition, in 2010, Karachay-Cherkess Republican madrasah boarding school was opened in the village of Uchkeken, Malokacharachayev district [2].

Constructive relations with federal and regional authorities have been built, and positive experience of cooperation agreements with state structures has been accumulated. In 1998, an agreement was concluded with the Ministry of Culture of the KCR. Active work was launched on the development and implementation of the training course "History and culture of traditional religions of the KCR peoples" through the agreement signed in 2005 with the Ministry of education and science of the KCR. Later, on the basis of the agreement, the Islamic clergy were involved in the development of a training package for students in grades 4-5 and teachers of the course "Fundamentals of religious culture and secular ethics". In 2008, the muftiat signed a cooperation agreement with the Central administration of the Ministry of Emergency Situations of the Russian Federation for the KCR. Similar agreements were signed by the Federal Drug Control Service Administration in the KCR (2010) [2]. Later, agreements were concluded with the Ministry of Internal Affairs for the KCR (2011) and the Department of the Federal Migration Service for the KCR (2012), as well as with such an authoritative public structure as the regional branch of the Russian Army, Air Force and Navy Volunteer Society (DOSAAF) (2011) [3].

Mufti Ismail-Khadzhi Berdiev is a member of the Public Chamber of the KCR, the Public Council under the Ministry of Internal Affairs for the KCR, the Commission under the President of the KCR on harmonizing interethnic relations, preventing extremism and destabilizing the situation in the republic, etc.

Also, constructive relations were established with the Russian Orthodox Church. Representatives of the Muslim and Orthodox clergy participated in socially significant events and spoke on issues relevant to modern society. 
By the beginning of the second decade of the XXI century, significant experience of interaction with the media was accumulated. The local television regularly aired programs: "On the way to faith" (weekly in Russian), "World of Islam" (monthly in the Abaza language), "Azan" (monthly in the Karachai language), "Word from the Koran" (monthly in Nogai language), "Minaret" (monthly in the Circassian language). The Republican Newspapers "Republic Day", "Karachay", "Circassian-heku", "Nogai davysy", "Abazashta" regularly published information and thematic materials on religious holidays and events in religious life. Attempts were also made to create a specialized publication. On February 19, 2001, the newspaper "al-Muslim-Musulmanin" was registered. The founder was the Karachay-Cherkess Islamic Institute named after Imam Abu-Hanif. The declared circulation was 1100 copies. However, after the death of the rector of the institute, Ismail-haji Bostanov, it was not possible to achieve regular publication of the newspaper. On October 17, 2012, the newspaper was eliminated by a court decision [12].

However, despite the obvious achievements, by the end of 2010, a significant number of difficult-to-solve issues had accumulated in the muftiate. The key problem that has not left the agenda since the formation of the muftiate in 1989 was the issue of countering religious and political extremism. The Muslim clergy were also targeted. In 2006, Anzor Astemirov ("Amir Seifullah") issued an appeal calling for the destruction of "traitors from among the imams". A real hunt began for honest imams who fought back against the terrorists. On August 5, 2006, Imam Abul-Kerim Bayramukov was killed in a mosque in the city of Karachaevsk right during namaz. On August 12, 2006, in front of his wife and daughter, Effendi Ismail Batchaev was killed. On September 25 of the same year a member of the Presidium of the Muslim Spiritual Directorate (later MSD) of the KarachayCherkess Republic and Stavropol Territory, the imam-khatyb of Kislovodsk Abubekir Kurdzhiev, was shot dead at the entrance of his house. The assassination of the deputy mufti of the Spiritual Directorate of Karachay-Cherkessia and Stavropol, the rector of the Karachay-Cherkess Islamic Institute Ismail Bostanov caused a wide resonance. On September 20,2009 , he was shot when he was returning home after namaz, at one of the crossroads at the entrance to Cherkessk. His son, who was in the car with him, was seriously injured.

As a result, by the end of the 2000s, the Muslim ummah of Karachay-Cherkessia was in a rather difficult situation - authoritative spiritual leaders who played an important role in the management of the muftiate were killed. But, despite the fact that the clergy was said to be on the front line of the fight against extremism, the work carried out by the muftiat at various meetings devoted to countering terrorism was assessed as insufficient. In order to increase the effectiveness of the fight against the spread of extremist ideology, the authorities of the Stavropol territory already in 1998 considered separating the independent Spiritual Directorate of the Stavropol territory from the MSD of KCR and Stavropol, which united the parishes of Karachay-Cherkessia and Stavropol. After the start of counter-terrorist operations in the North Caucasus, this idea faded into the background. They returned to it again in 2004, but it was possible to create a new Muftiate only in 2010 [5]. On April 27, 2010, the founding Congress of the centralized religious organization "Muslim Spiritual Directorate of the Stavropol territory" was held in Stavropol.

Thus, the Ummah of the Stavropol territory, which is comparable in size to the Ummah of Karachay-Cherkessia, came out of Muftiate control. The task was not only to bring the legal status of the Muftiate in accordance with the prevailing realities, but also to reform the Ummah's management system with utmost seriousness.

In 2010, in preparation for the next, VIII Congress of Muslims of KarachayCherkessia and Stavropol, the leadership of the muftiat carried out a serious analysis of Spiritual Directorate work, identified a set of shortcomings in the work that did not allow the muftiate to fully function and effectively solve emerging problems. 
First of all, there was a lack of coordination at the level of the mufti, the Plenum and the Presidium. The meetings of the plenum and the presidium were ad hoc in nature, and there was no system for monitoring the execution of instructions. Office management and accounting were entrusted to one person, the executive secretary, who worked on a pro bono basis and did not have the necessary qualifications. The work on the preparation and issuance of fatwas and khutbahs, the main instruments of influence of the Muslim clergy on the ummah, was not organized.

Another problem was the lack of involvement of young imams in the work of the muftiate. A significant number of young people who received an Islamic education were not involved in the work of the muftiat. As a result, an unacceptable situation arose when people in authority among Muslims were not in demand in the daily administrative work of the Directorate. In addition, there was no rotation of personnel within the muftiate, and no personnel reserve was formed. This significantly reduced the effectiveness of the work of the Spiritual Directorate, strengthened the idea of the muftiate as an inert, closed structure, whose leadership had low authority in theological matters.

Before the withdrawal of the Stavropol jamagats from the Spiritual Directorate, there were about 150 communities in the muftiate, it was the largest Muslim organization in the Northwest Caucasus. (jamagat - mosque parish, ummah, community of mu'mins in KCR) At the same time, financial discipline was at an extremely low level. The contributions of local communities to the needs of the Spiritual Directorate were not regular, and their size was insufficient to meet even the minimal needs of the muftiate and the Islamic institute. It is indicative that for 20 years it was not possible to solve the problem with the acquisition of premises for the office of the Spiritual Directorate.

The incident with the decision of a number of imams to take part in the 2009 local election campaign was an alarming signal that showed the decrease in the authority of the mufti. The Mufti's explicit ban on engaging in politics was perceived only by some imams. Another part, led by the rais-imam of the Ust-Dzhegutinsky region, ignored the ban [4]. (rais-imam - senior imam in KCR)

The Eighth portback election Congress of Muslims of Karachay-Cherkessia and Stavropol Territory gave a start to radical transformations. The congress was held on March 16, 2011. The decisions taken at the congress and the administrative work carried out in subsequent years significantly changed the muftiat system of governance and influenced the work of the Spiritual Directorate in the next decade.

The congress consolidated the withdrawal of the Stavropol Ummah and adopted a new charter, which reflected the new name of the Muftiate - the Spiritual Directorate of Karachay-Cherkessia Republic Muslims - and made necessary general organizational changes. The number of members of the Presidium was reduced from 11 to 6 people.

After the congress a new management structure of the muftiat was formed. In addition to the statutory audit commission, completely new structures were created within the Spiritual Directorate, the work of which was supervised by the members of the presidium. The Mufti, in addition to the general management of the Directorate and the performance of representative functions, coordinated the work of the Revision Commission, the Council of Elders, and the Ulema Council. The deputy and the executive secretary, as well as the staff of assistants, reported directly to him. The hajj department, the youth affairs department, the dawah department, the department for interaction with educational institutions, those responsible for the districts were closed to the deputy mufti [7].

In 2013, the status of the Presidium members was changed. The Mufti's decree of May 23, 2013 established the positions of Qadi of Muslims of Karachay-Cherkessia Republic and Qadis of national parishes. The members of the Presidium of the Spiritual Directorate began to perform these functions. In their activities, the national parishes' Qadis were directly subordinated to the Karachay-Cherkessia Republic Muslims' Qadi. Respon- 
sible for work in cities and districts, imam-hatibs of mosques were instructed to coordinate their activities with the Qadis [9].

Perhaps, for the first time, the muftiat management system was spelled out in such detail. All major areas of work were covered. A rigid hierarchical subordination of the administrative structures of the Spiritual Directorate was established.

The role of the deputy mufti in the new management system was significantly strengthened, and he coordinated all the current work of the muftiate. These changes, as well as the elimination of the institution of rais-imams were not met with enthusiasm among the clergy - some of the most ambitious imams concentrated on working in local jamagats, while others completely retired. However, on the whole, the established structure was distinguished by a certain logic and, as time has shown, was resilient.

The objective task facing the muftiate was the involvement of young clergy in constructive work. The proposed scheme was quite suitable for this. Young authoritative imams were included in the Council of Alims (Ulamas) and profile departments: on work with youth, dawah (missionary work), hajj, interaction with educational institutions. Thus, instead of being pushed to the periphery of religious life, young professionally trained imams were given the opportunity to work constructively within the existing structures. The involvement of educated clergy has improved the quality of discussion of controversial issues within the muftiat, as well as more effectively counteract the spread of extremist ideology.

In this regard, the situation that arose in the jamagat of the mosque of the village of Besleney of the Khabez district is indicative [6]. In 2016, Anzor Urezhev began preaching here. He graduated from an Islamic school in Egypt and was fluent in Arabic, so he commanded the respect of the worshippers. The Imam entrusted him to teach the basics of Islam after the evening namaz. At first, many parishioners came to him. However, it soon became clear that during the classes $A$. Unezhev promoted the teachings of the banned organization "at takfir wal-hijra" (banned in the territory of the Russian Federation). The imam of the mosque forbade A. Unezhev to conduct classes, after which a group of his supporters began to gather in the quarter mosque.

At night, after the last namaz, Anzor conveyed his beliefs to his supporters, explaining to them the theoretical provisions of "takfir" (accusation of disbelief) according to the teaching of "At Takfir wal-Hijra" (banned on the territory of the Russian Federation). A. Unezhov urged supporters to carry out "dawah" (call to Islam) among young people in the village and district in order to increase the number of like-minded people. Anzor also expressed the opinion that in the territory of North Caucasian republics, where the population is mostly Muslim, a state with a Shariah form of government should be built. He called for non-compliance with secular laws and established norms of the so-called "Tagut State", to which he referred the Russian Federation, and spoke negatively about the Muslims who were in the civil service.

In the end, a separate jamia was formed in the quarter mosque, which followed only the ideology of "At takfir wal-Hijra" (banned in the territory of the Russian Federation). The imam's attempts to persuade them to abandon radical ideology and return young people to the region's traditional Islam were unsuccessful. They also rudely rejected the village elder, who urged them to return to the central mosque.

The culmination of the situation was the announcement of takfir to the local imam. Takfir - the accusation of kufr, disbelief - is a very serious accusation, because, according to the canon, the refusal to believe in the Almighty and his Prophets, is punishable by death.

In this situation, Ruslan Khakirov, a representative of the new generation of clergy, who joined the administration of the muftiate as a result of the reforms, has proven to be a worthy representative. Khakirov explicitly demanded that A. Unezhev outline the dogmati- 
cally substantiated motives for accusing the honoured Imam in kufr. In response, Unezhev could only present the imam's compliance with the laws of the Russian Federation and participation in the Victory Day celebrations. It was quite obvious that such accusations contradict not only the secular law, but also the norms of Islamic law - figh.

The panelists recounted: "Don't you accept the laws of the secular state?" - Ruslanhadji asked - "Then why do you use all his attributes, including passport and bank notes? Set an example, give up this "filth"! Are you issuing takfir to an elderly imam who does namaz daily, keeps fasting, has made hajj, and certainly has never renounced the Almighty and his Prophets, and do your own parents, who had the misfortune of living under an atheistic state, know how to do namaz? If not, issue takfir to your own mother!" [10]

In addition to the obvious arguments, Khakirov suggested taking the conversation to a higher level, involving authoritative independent theologians. However, there was no continuation of the discussion. Under the pretext of consulting A. Unezhev left the country, the remaining members of the group, who did not stop spreading the ideology of the organization banned in Russia, were prosecuted.

It is indicative in this situation that before applying force to the radical group active in the village, measures of persuasion in various formats were taken - from attempts by representatives of the older generation to influence young people to theological discussion. That was very important in order to publicly demonstrate the perniciousness of the extremist doctrine, its inconsistency with the canons of Islam, and to prevent extremists from developing a crown of martyrdom, hounded by law enforcement agencies.

The situation confirmed the ability of the local clergy to openly confront representatives of the radical community in a dignified manner and confirmed the legitimacy of involving young, educated clergy in their work.

During the same period, the activities of several radical communities were suppressed in the republic, the most active of which was an extremist group established in 2011 by Islam Uzdenov. The extremists took the organization of their formation very seriously. Umar Baychorov was elected "Amir"; subordination hierarchical structure of members of the illegal armed formation (hereinafter - the "IAF") to a single leader was established; couriers were identified; food, special uniforms and medicines, weapons and ammunition were purchased. The goal of the group was the violent seizure of power with the subsequent change of the constitutional system of the Russian Federation in the North Caucasus and the creation of a state with a Sharia form of government on its territory. The first priority was the elimination of law enforcement officers. On account of the criminalsfive killed and many wounded law enforcement officers. The elimination of the IAF was time-consuming and demanding. Eight active members of the group, including Islam Uzdenov and Umar Baychorov, were killed during armed resistance during detention. As a result, 16 people were brought before the court. In 2014, all of them were sentenced to different terms of punishment. Two of them (Denislam Semenov and Osman Baichorov) received 18 and 17 years of high-security imprisonment [11].

Another important area of work of the Spiritual Directorate during this period was active interaction with the media. During the period under review, the information space of the republic significantly expanded due to the launch in 2014 of the round-the-clock satellite TV channel "Arkhyz 24", whose management paid great attention to religious topics. The channel devoted two projects directly to Islam. One of them is "Nur". - a weekly religious television programme in which representatives of the clergy answer topical questions related to Islam. Another is the Program "Islam is my Religion", which reveals the history of the creation and highlights the activities of religious Muslim buildings, mosques and regional Islamic educational institutions, as well as outstanding personalities of Islam living in the republic. 
In 2016, with the support of the Ministry of Nationalities, Mass Communications and Press of the KCR, an attempt was made to launch the Spiritual Directorate's own website. The structure of the site included a news section, information about the Muftiyat, information about Islamic doctrine, the Muslim calendar, the schedule of namaz, as well as special sections for women and neophytes [8]. Unfortunately, the project was canceled in the following years.

In this article we have touched upon only some development aspects of the Muslim ummah of Karachay-Cherkessia in the second decade of the XXI century.

The system of administration developed after the Eighth Congress ensured stable work of the Spiritual Directorate of the KCR during the whole subsequent decade. The Ninth Congress did not make any adjustments to this system. This system has successfully solved the main issues facing the muftiat: both the daily issues related to the functioning of mosques, development of fatwas and khutbahs, and quite complex, such as the organization of Hajj, combating the spread of extremist ideology. The involvement of educated young people in the muftiate was of great importance, as it made it possible to prevent the marginalization of young worshippers and attract them to constructive work. The problem of religious extremism has retained its relevance, but its scope has significantly narrowed and it does not have a broad impact on the public consciousness of this ideology.

The downside of such stability was some stagnation: the composition of the management structures has not been practically renewed for 10 years. New forms of work using modern resources, such as the Internet and social networks have not been introduced. One way or another, a set of problematic issues requiring reflection and solution has been formed for the Eighth portback election Congress to be held in March 2021. It is obvious that the success of their solution will determine the direction and success of the republic's Ummah in the near future.

\section{Лumepamypa}

1. Итоги Всероссийской переписи населения по Карачаево-Черкесской Республике: Т.3. «Национальный состав и владение языками, гражданство» // КарачаевоЧеркесскстат. Черкесск. 2013.

2. Личный архив автора (далее - ЛАА) «Информация о деятельности органов государственной власти Карачаево-Черкесской Республики в сфере взаимодействия с религиозными объединениями в 2010 г.».

3. ЛАА. «Информация о деятельности органов государственной власти Карачаево-Черкесской Республики в сфере взаимодействия с религиозными объединениями в 2011 г.» «Информация о деятельности органов государственной власти Карачаево-Черкесской Республики в сфере взаимодействия с религиозными объединениями в 2012 г.».

4. ЛАА. О системе управления в Карачаево-Черкесском муфттияте после VIII Съезда мусульман КЧР и Ставропольского края. Служебная записка. 29.06.2012

5. ЛАА. О создании Ставропольского муфтията. Аналитическая записка. 04.04.2010.

6. ЛАА. Протокол опроса Лахова Арсена Инусовича, составлен 26.05.2018. Электронная копия; Протокол опроса Бакирова Сафир Черкез-оглы, составлен 27.05.2018. Электронная копия.

7. ЛАА. Распределение обязанностей между руководством ДУМ КЧР. Электронная копия. 
8. ЛАА. Техническое задание на редакционное ведение и администрирование сайта Духовного Управления Мусульман КЧР в рамках реализации программы по профилактике терроризма и экстремизма. Электронная копия.

9. ЛАА. Указ Муфтия ДУМ КЧР от 23.05.2013. Электронная копия.

10. Полевые материалы автора. Беседы с мусульманским духовенством. 18.07.2020.

11. Приговор Верховного Суда КЧР по делу № 2-13/2014 (2-40/2013)

12. Роскомнадзор. Официальный сайт. Перечень наименований зарегистрированных CMИ. URL: https://rkn.gov.ru/mass-communications/reestr/media/?id=253695 (Дата обращения 18.10.2020)

\section{References}

1. Dzhanteeva D. Vozmozhna li peredacha alanskikh khramov RPTS? [Is it possible to transfer Alan churches to the Russian Orthodox Church?].

Available at: http://skfonews.info/article/108\&p=2\&c=1 (accessed:14 February 2020) (In Russian).

2. Itogi Vserossiyskoy perepisi naseleniya po Karachayevo-Cherkesskoy Respublike: T.3. «Natsionalnyy sostav i vladeniye yazykami, grazhdanstvo» [Results of the AllRussian population census in the Karachay-Cherkess Republic: V.3. "Ethnic composition and language skills, citizenship"]. Karachay-Cherkesskstat. Cherkessk, 2013 (In Russian).

3. Lichnyy arkhiv avtora (daleye - LAA) «Informatsiya o deyatelnosti organov gosudarstvennoy vlasti Karachayevo-Cherkesskoy Respubliki $v$ sfere vzaimodeystviya s religioznymi obyedineniyami v 2010 g.» [Personal archive of the author (hereinafter LAA) "Information on the activities of state authorities of the Karachay-Cherkess Republic in the field of interaction with religious associations in 2010"] (In Russian).

4. LAA. «Informatsiya o deyatelnosti organov gosudarstvennoy vlasti KarachayevoCherkesskoy Respubliki v sfere vzaimodeystviya $s$ religioznymi obyedineniyami v 2011 g.» «Informatsiya o deyatelnosti organov gosudarstvennoy vlasti KarachayevoCherkesskoy Respubliki v sfere vzaimodeystviya s religioznymi obyedineniyami v 2012 g.» [LAA. "Information on the activities of public authorities of the Karachai-voCherkess Republic in the field of interaction with religious associations in 2011" "Information on the activities of public authorities of the Karachay-Cherkess Republic in the field of interaction with religious associations in 2012"] (In Russian).

5. LAA. O sozdanii Stavropolskogo muftiyata. Analiticheskaya zapiska. 04.04.2010 [LAA. On the creation of the Stavropol Muftiate. Analytic note. 04.04.2010] (In Russian).

6. LAA. Protokol oprosa Lakhova Arsena Inusovicha, sostavlen 26.05.2018. Elektronnaya kopiya; Protokol oprosa Bakirova Safir Cherkez-ogly, sostavlen 27.05.2018. Elektronnaya kopiya [LAA. The protocol of the survey of Arsen Inusovich Lakhov, compiled on May 26, 2018. Digital copy; Safir Cherkez-oglu Bakirov's interview protocol, compiled on 05/27/2018. Digital copy] (In Russian).

7. LAA. Raspredeleniye obyazannostey mezhdu rukovodstvom DUM KCHR. Elektronnaya kopiya [Distribution of responsibilities between the leadership of the SAM KChR. Digital copy] (In Russian).

8. LAA. Tekhnicheskoye zadaniye na redaktsionnoye vedeniye i administrirovaniye sayta Dukhovnogo Upravleniya Musulman KCHR v ramkakh realizatsii programmy po profilaktike terrorizma i ekstremizma. Elektronnaya kopiya [LAA. Terms of reference for the editorial maintenance and administration of the website of the Spiritual Direc- 
torate of Muslims of the KChR as part of the implementation of the program for the prevention of terrorism and extremism. Digital copy] (In Russian).

9. LAA. Ukaz Muftiya DUM KCHR ot 23.05.2013. Elektronnaya kopiya [LAA. Decree of the Mufti DUM KCHR dated 23.05.2013. Digital copy] (In Russian).

10. Polevyye materialy avtora. Besedy s musulmanskim dukhovenstvom. 18.07.2020 [Field materials of the author. Conversations with Muslim clergy. 18.07.2020] (In Russian).

11. Prigovor Verkhovnogo Suda KCHR po delu № 2-13/2014 (2-40/2013) [Verdict of the Supreme Court of the KChR in case No. 2-13/2014 (2-40/2013)] (In Russian).

12. Roskomnadzor. Ofitsialnyy sayt. Perechen naimenovaniy zaregistrirovannykh SMI. [Roskomnadzor. Official site. List of the names of the registered mass media] (Available at: https://rkn.gov.ru/mass-communications/reestr/media/?id=253695, (accessed: 18 October 2020) (In Russian). 